\title{
A krónikus obstruktív tüdőbetegség metabolikus következményei
}

\author{
Fekete Mónika dr. ${ }^{1}$ - Fazekas-Pongor Vince dr. ${ }^{1}$ \\ Szőllősi Gergő ${ }^{2}$. Varga János Tamás dr. ${ }^{3}$ \\ ${ }^{1}$ Semmelweis Egyetem, Általános Orvostudományi Kar, Népegészségtani Intézet, Budapest \\ ${ }^{2}$ Debreceni Egyetem, Népegészségügyi Kar, Családorvosi és Foglalkozás-egészségügyi Tanszék, Debrecen \\ ${ }^{3}$ Országos Korányi Pulmonológiai Intézet, Budapest
}

\begin{abstract}
Bevezetés: Krónikus obstruktív tüdőbetegségben (COPD) az obesitas mellett a csökkent fizikai aktivitás nagymértékben fokozza a metabolikus szindróma kialakulásának valószínúségét.

Célkitüzés: Kutatásunk célja volt felmérni a metabolikus szindróma prevalenciáját COPD-ben, valamint azt, hogy milyen mértékben függ össze az életkorral, a nemmel, a társbetegségekkel, a tüdőfunkció károsodásának mértékével, a tápláltsági állapottal, a fizikai terhelhetőséggel és az életminőséggel.

Módszer: Keresztmetszeti vizsgálatot végeztünk az Országos Korányi Pulmonológiai Intézet Légzésrehabilitációs Osztályán fekvő betegek körében 2019. július 1. és december 31. között. A véletlenszerúen kiválasztott 300,40 év feletti betegnek ismertük az antropometriai, légzésfunkciós vizsgálati eredményét és laboratóriumi paramétereit. Adatokat gyưjtöttünk a dohányzási szokásokról, az előző évi exacerbatiók számáról és a kortikoszteroidok használatáról is. Az életminőség mérésére a betegségspecifikus Szent György-féle Légzési Kérdőív magyar nyelvre validált változatát használtuk. A metabolikus szindrómát a Nemzetközi Diabetes Szövetség kritériumai alapján határoztuk meg.

Eredmények: A metabolikus szindróma a betegek 72\%-ánál fordult elő, férfi: $65,9 \%$ nő: 77,2\% (p = 0,031). A metabolikus szindrómás betegek esetében rövidebb 6 perces sétatávolságot mértünk ([m] 250 [150-330] vs. 295 [162$360] ; \mathrm{p}=0,384)$, és szignifikánsan több volt az előző évi exacerbatiók száma (3 [0-6] vs. l [1-2]; p<0,001) a nem metabolikus szindrómás betegekhez képest . A BMI-re történő stratifikáció után a metabolikus szindróma jelenléte nagyobb volt $\mathrm{BMI} \geq 25 \mathrm{~kg} / \mathrm{m}^{2}$ esetén. A hasi elhízás, a magas vérnyomás, a hyperlipidaemia és a hyperglykaemia szignifikánsan gyakoribb volt $\mathrm{BMI} \geq 25 \mathrm{~kg} / \mathrm{m}^{2}$ esetén $(\mathrm{p}<0,001)$.

Következtetés: Eredményeink azt sugallják, hogy a metabolikus szindrómás betegekben megnó az együttes morbiditási index, különösen azok körében, akik túlsúlyosak vagy elhízottak. Ezért a COPD-s betegekben nagyon fontos időben felismerni és megfelelően kezelni a metabolikus szindrómát.

Orv Hetil. 2021; 162(5): 185-191.
\end{abstract}

Kulcsszavak: krónikus obstruktív tüdőbetegség, metabolikus szindróma, obesitas, életminőség

\section{Metabolic consequences of chronic obstructive pulmonary disease}

Introduction: Both obesity and the lack of physical activity among chronic obstructive pulmonary disease (COPD) patients increase the risk of developing metabolic syndrome.

Objective: The goal of our study was to assess the prevalence of metabolic syndrome among COPD patients and to examine its correlation with age, gender, comorbidities, lung function values, nutritional status, exercise capacity, and quality of life.

Method: A cross-sectional study was performed at the Department of Pulmonary Rehabilitation of the Hungarian National Korányi Institute for Pulmonology between July lst and December 31st, 2019. A total of 300 patients aged over 40 were selected at random. Anthropometric data were collected along with lung function values, laboratory parameters, smoking status, the number of exacerbations in the previous year, and the use of corticosteroids. Quality of life was measured by the validated Hungarian, COPD-specific Saint George Respiratory Questionnaire. Metabolic syndrome was defined according to the International Diabetes Federation criteria.

Results: Metabolic syndrome affected $72 \%$ of COPD patients (male: $65.9 \%$, female $77.2 \% ; \mathrm{p}=0.031$ ). In patients with metabolic syndrome, shorter 6-minute walking distance was measured ([m] 250 [150-330] vs. 295 [162-360]; $\mathrm{p}=0.384)$ and the number of exacerbations in the previous year was significantly higher (3 [0-6] vs. 1 [1-2]; $\mathrm{p}<0.001)$ compared to patients with no metabolic syndrome. After stratification for BMI, metabolic syndrome was more frequent in the case of $\mathrm{BMI} \geq 25 \mathrm{~kg} / \mathrm{m}^{2}$. Central adiposity, hypertension, hyperlipidemia, and hyperglycemia were also significantly more frequent among patients with $\mathrm{BMI} \geq 25 \mathrm{~kg} / \mathrm{m}^{2}(\mathrm{p}<0.001)$. 
Conclusion: Our results suggest that the co-morbidity index increases in patients with metabolic syndrome, especially in overweight or obese patients. Therefore, early detection and appropriate treatment of metabolic syndrome in patients with COPD is very important.

Keywords: chronic obstructive pulmonary disease, metabolic syndrome, obesity, quality of life

Fekete M, Fazekas-Pongor V, Szőllősi G, Varga JT. [Metabolic consequences of chronic obstructive pulmonary disease]. Orv Hetil. 2021; 162(5): 185-191.

(Beérkezett: 2020. július 6.; elfogadva: 2020. július 26.)

\begin{abstract}
Rövidítések
$6 \mathrm{MWD}=(6$-minute walking distance $) 6$ perces sétatávolság; $\mathrm{BMI}=($ body mass index $)$ testtömegindex $; \mathrm{COPD}=($ chronic obstructive pulmonary disease) krónikus obstruktív tüdőbetegség; $\mathrm{FEV}_{1}=$ (forced expiratory volume in the first second) erőltetett kilégzés első másodpercében kifújt volumen; FVC = (forced vital capacity) erőltetett kilégzési vitálkapacitás; GOLD $=($ Global Initiative for Obstructive Lung Disease $)$ a COPD súlyossági fokát besoroló nemzetközi ajánlás; $\mathrm{HbA}_{\mathrm{lc}}=$ hemoglobin-Alc (glikált hemoglobin); HDL = (high-density lipoprotein $)$ nagy sûrüségű lipoprotein; IDF $=($ International Diabetes Federation) Nemzetközi Diabetes Szövetség; LDL = (low-density lipoprotein) alacsony sűrűségű lipoprotein; SGRQ = (St. George's Respiratory Questionnaire) Szent György-féle Légzési Kérdőív; TUKEB = Tudományos és Kutatásetikai Bizottság; VLDL = (very low-density lipoprotein) nagyon alacsony sűrúségű lipoprotein
\end{abstract}

A krónikus obstruktív tüdőbetegség (COPD) megelőzhető és kezelhető népbetegség több jelentős extrapulmonalis következménnyel, melyek a kórállapot kimenetelét befolyásolhatják [1]. A világon jelenleg negyedik vezető halálokként tartják számon, s az előrejelzések szerint várhatóan a harmadik legjelentősebb halálokká válik 2030-ra [2]. A légúti obstrukció a tüdő kóros gyulladásos reakciójának következménye, melyet szövetkárosító gázok és részecskék - jelentős mértékben a dohányfüst - inhalációja vált ki [3]. A fóleg 40 év feletti, dohányzó egyénekben kialakuló COPD mellett több társbetegség is fennállhat; prevalenciájuk a betegekben nagyon gyakori, akár 60-85\%-ban is elöfordulhat, a leggyakrabban hypertonia, ischaemiás szívbetegség, szívelégtelenség, tüdőrák, diabetes mellitus, osteoporosis, szorongás, depresszió, anaemia társulásával kell számolni [4]. A hasi zsírszövet jelentős megnövekedése közvetlen összefüggést mutat az atheroscleroticus eredetü érbetegségek okozta szervkárosodások, elsősorban a myocardialis infarctus kialakulásának valószínüségével; ennek hátterében a visceralis zsírszövet által termelt, adipokineknek nevezett polipeptidek állnak, melyek vérnyomásemelő, atherogen, thrombogen, illetve inzulinrezisztenciát kiváltó hatásaik révén számos támadásponton megsokszorozzák az érbetegségek valószínüségét [5]. A hyperinsu- linaemia következménye a májban a fokozott VLDL-termelés és a trigliceridben gazdag atherogen lipoproteinek megszaporodása (csökkent HDL-, emelkedett LDL-koleszterin-szint és tartós hypertriglyceridaemia) [6]. A fibrinolitikus aktivitás csökkenése (például a plazminogénaktivátorinhibitor-1 termelődése) prothrombogen állapotot okoz. Mindezek a hatások összességében fokozott oxidatív stresszt, vascularis gyulladást alakítanak ki. A közelmúlt megfigyelései arra hívták fel a figyelmet, hogy a túlsúlyos, COPD-ben szenvedő betegek körében gyakoribb a metabolikus szindróma a korban és testtömegindexben (BMI) azonos egészséges egyének csoportjához viszonyítva, és a COPD-ben és metabolikus szindrómában szenvedők fizikai terhelhetősége is csökkent a tisztán COPD-ben szenvedők teljesítményéhez képest. Néhány tanulmány szerint a COPDben szenvedő betegek magasabb koleszterin- és vérzsírszintje súlyosabb stádiumú betegséggel és gyakoribb exacerbatiókkal társul [7, 8].

Kutatásunk célja volt felmérni a különböző tápláltsági állapotú, COPD-s betegek életminőségét, társbetegségeinek gyakoriságát, a metabolikus szindróma prevalenciáját, valamint azt, hogy milyen mértékben függ össze az életkorral, a nemmel, egyéb társbetegségekkel, a tüdőfunkció károsodásának mértékével ( $\left.\mathrm{FEV}_{1} \mathrm{ref} \%\right)$, a tápláltsági állapottal (BMI), a fizikai terhelhetőséggel (6 perces sétatávolság - 6MWD) és az életminőséggel (Szent György-féle Légzési Kérdőív - SGRQ-C). Kutatásunkban a Nemzetközi Diabetes Szövetség (IDF) által meghatározott diagnosztikai kritériumrendszert használtuk a metabolikus szindróma definíciójaként [9].

\section{Módszer}

Az Országos Korányi Pulmonológiai Intézet 300, COPDben szenvedő betegénél végeztünk keresztmetszeti vizsgálatot. A betegek a felmérés előtt szóbeli és írásbeli tájékoztatást kaptak, majd aláírták a beleegyező nyilatkozatot. A vizsgálatot a TUKEB etikai bizottsága jóváhagyta (engedélyszám: TUKEB 44402-2/2018/EKU), a kutatás megfelel a Helsinki Deklarációban foglaltaknak. A kutatásba történő bevonás kritériumai a következők voltak: 
40 év feletti életkor, diagnosztizált COPD (post-bronchodilator $\mathrm{FEV}_{\mathrm{l}} / \mathrm{FVC}<70 \%$ ) (10]. A COPD akut exacerbatio kritériuma, ha a következő négy tünet közül legalább kettő fennáll (Anthonisen-kritériumok): 1) fokozódó mennyiségú, purulens köpet ürül, 2) a tüdőfunkció romlik, a légzési panaszok súlyosbodnak, 3 ) a beteg lázas és/ vagy 4 ) leukocytosis jelentkezik.

Minden egyes betegnél megmértük a post-bronchodilator $\mathrm{FEV}_{\mathrm{l}}$-értéket (eróltetett kilégzés első másodpercében kifújt volumen), és a becsült értékek százalékában fejeztük ki. A betegeket GOLD A-D stádiumba soroltuk az aktuális és a jövőbeli kockázat paraméterei alapján, a spirometriás értékek, a tünetek és az exacerbatiós ráta szerint [10]. Az életminőség mérésére a betegségspecifikus SGRQ-C [11] magyar nyelvre validált változatát használtuk, mely 40 kérdést tartalmaz. Ez a kérdőív az életminőséget befolyásoló tényezőket három kategóriában vizsgálja: tüneti, aktivitási és a tüdőbetegség mindennapi életre gyakorolt hatását vizsgáló szegmens. Az egyes válaszok súlyszámértéke alapján számolhatók a különböző dimenziók súlyszámai, valamint ezek összegéből az összpontszám értéke. Ennél a kérdőívnél a magasabb pontértékek rosszabb életminőséget jeleznek. A kérdőívet a betegek stabil állapotban az intézményben töltötték ki, koordinátor felügyelete mellett.

A metabolikus szindróma definícióját az IDF által meghatározott diagnosztikai kritériumrendszer szerint alkalmaztuk [9]. Az ajánlás szerint a metabolikus szindróma diagnózisának megállapításához a következők jelenléte szükséges: centrális típusú elhízás: 94 cm-nél nagyobb derékkörfogat a férfiak és $80 \mathrm{~cm}$-nél nagyobb a nők esetében, emellett a következő négy faktor közül bármelyik kettő jelenléte:

- emelkedett éhgyomri vércukorszint: 25,6 mmol/1, vagy korábban diagnosztizált 2 -es típusú cukorbetegség;

- emelkedett trigliceridszint: 1,7 mmol/l-nél nagyobb érték, vagy e kóros lipidparaméter miatt folytatott specifikus kezelés;

- alacsony HDL-koleszterin-szint: 1,29 mmol/l-nél alacsonyabb a férfiak és 1,03 mmol/l-nél alacsonyabb a nők esetében, vagy e kóros lipidparaméter miatt folytatott specifikus kezelés;

- emelkedett vérnyomás: systolés érték $\geq 130$ Hgmm vagy diastolés érték $\geq 85 \mathrm{Hgmm}$, vagy korábban diagnosztizált hypertonia miatt folytatott kezelés.

A 6MWD mérésekor a betegeket arra kértük, hogy hat percig sétáljanak a folyosón, és ennek során detektáltuk a maximális sétatávolságot [12]. A BMI meghatározásához a kilogrammban mért testtömeget elosztottuk a méterben mért testmagasság négyzetével $\left(\mathrm{kg} / \mathrm{m}^{2}\right)$. Éhomi vérmintát gyüjtöttünk az Országos Korányi Pulmonológiai Intézet központi laboratóriumában a lipidprofil (teljes koleszterin, trigliceridek, LDL és HDL) meghatározására. A vérvételi vizsgálatot a betegek klinikailag stabil, lázmentes és légúti fertőzéstől mentes állapotában végeztük.

\section{Statisztikai analízis}

A leíró elemzéseket a STATA SE-10.0 (StataCorp, College Station, TX, USA) programcsomaggal végeztük. A minta eloszlását Shapiro-Wilk-teszttel ellenőriztük; a folytonos változók nem normáleloszlást mutattak, ezért medián és interkvartilis terjedelemben adtuk meg a táblázatok adatait. A csoportok közötti különbségeket Kruskal-Wallis-próbával elemeztük. A statisztikai próbákat 95\%-os konfidenciaintervallum mellett végeztük, és a szignifikancia értéke $\mathrm{p}<0,05$ volt.

\section{Eredmények}

A vizsgálatba 300 , stabil állapotú COPD-s beteget vontunk be. A betegek medián életkora 67 (62-73) év volt, a vizsgálatban részt vevők aránya: $46 \%$ férfi és $54 \%$ nő; a betegek demográfiai tulajdonságait és a dohányzás előzményeit az 1. táblázatban mutatjuk be. A betegek 6,3\%a soha nem dohányzott, több mint fele $(52,7 \%)$ már leszokott a dohányzásról, és 41\%-a jelenleg is dohányzó. A betegek GOLD-stádium szerinti megoszlása: GOLD A: $5,6 \%$, GOLD B: 35\%, GOLD C: $46 \%$ és GOLD D: $13,4 \%$.

BMI-re történő stratifikáció után a betegek 8,6\%-ának BMI-je $21 \mathrm{~kg} / \mathrm{m}^{2}$ alatt volt, 28,0\%-uknak $21-25 \mathrm{~kg} / \mathrm{m}^{2}$ között, és kb. a kétharmaduk $(63,4 \%)$ volt a 'túlsúlyos, elhízott' (BMI> $\left.25 \mathrm{~kg} / \mathrm{m}^{2}\right)$ kategóriában. A betegek tápláltsági állapota $(\mathrm{BMI})$ szignifikáns összefüggést mutatott a vérnyomással (136/80 vs. 149/86; p<0,001), a légzésfunkcióval ( $\mathrm{FEV}_{1} \mathrm{ref} \%$ : 41 [34-48] vs. 49 [40-62]; $\mathrm{p}=0,049$ ), a lipidprofilokkal (HDL-koleszterin: 1,5 $[1,2-1,7]$ vs. $1,3[1,0-1,5] ; \mathrm{p}=0,022$; trigliceridek: 1,3 $[1-1,6]$ vs. 1,6 [1,2-2,1]; p = 0,047), az életminőséggel [SGRQ-C: 56,8 [42,5-67,0] vs. 49,8 [34,0-63,1]; p = $0,002)$, valamint a társbetegségekkel is (hypertonia $[\mathrm{p}=$ $0,007]$, cukorbetegség $[\mathrm{p}=0,020]$, ischaemiás szívbetegség $[\mathrm{p}=0,011])$.

A metabolikus szindróma prevalenciája magasabb volt a túlsúlyos/elhízott betegek között (BMI>25 kg/m²) $(\mathrm{p}<0,0001)$ (1. táblázat), elófordulási gyakorisága a teljes betegpopulációban: 72\%; a nők esetében gyakoribbnak bizonyult $(77,2 \%)$, mint a férfiak esetében $(65,9 \%)$, a különbség szignifikáns volt $(\mathrm{p}=0,031)$ (2. táblázat). A metabolikus szindróma előfordulási gyakorisága a különböző GOLD-stádiumokban: GOLD A: 82,3\%, GOLD B: 70,5\%, GOLD C: 71,0\% és GOLD D: 75,0\% (3. táblázat).

Azon COPD-s betegek esetében, akiknek metabolikus szindrómájuk volt, rövidebb 6MWD-t mértünk ([m] 250 [150-330] vs. 295 [162-360]; p = 0,384), és szignifikánsan több volt az előzó évi exacerbatiók száma (3 [0-6] vs. $1[1-2] ; \mathrm{p}<0,001)$, mint azon betegek esetében, akiknek nem volt metabolikus szindrómájuk (2. táblázat). 
1. táblázat | A COPD-s betegek jellemzői BMI-kategóriák szerint

\begin{tabular}{|c|c|c|c|c|}
\hline & $\begin{array}{c}\text { Alultáplált } \\
\text { BMI<21 kg/m² } \\
\text { n }=26\end{array}$ & $\begin{array}{c}\text { Normál súlyú } \\
\text { BMI } 21-25 \mathrm{~kg} / \mathrm{m}^{2} \\
\mathrm{n}=84\end{array}$ & $\begin{array}{l}\text { Túlsúlyos/Elhízott } \\
\text { BMI>25 kg/m² } \\
\text { n }=190\end{array}$ & p-érték \\
\hline Kor (év) (IQR) & $69(65-73)$ & $70(63-75)$ & $67(61-72)$ & 0,036 \\
\hline Férfi (fo, \%) & $11(42,31)$ & $44(52,38)$ & $83(43,68)$ & 0,218 \\
\hline Nő (fö, \%) & $15(57,69)$ & $40(47,62)$ & $107(56,32)$ & \\
\hline \multicolumn{5}{|l|}{ Dohányzási státusz } \\
\hline Aktívan dohányzó (fö, \%) & $14(53,85)$ & $31(36,91)$ & $78(41,05)$ & 0,122 \\
\hline Leszokott dohányzó (fö, \%) & $10(38,46)$ & $44(52,38)$ & $104(54,73)$ & \\
\hline Soha nem dohányzó (fó, \%) & $2(7,69)$ & $9(10,71)$ & $8(4,21)$ & \\
\hline Dohányzás (év) & $41(26-50)$ & $40(25-48)$ & $37(25-60)$ & 0,842 \\
\hline Cigaretták száma (szál/nap) & $20(12-21)$ & $17(10-20)$ & $20(15-21)$ & 0,049 \\
\hline Testtömeg (kg) & $52(48-55)$ & $64(60-69)$ & $84(73-95)$ & $<0,0001$ \\
\hline Testmagasság (cm) & $167(158-171)$ & $167(159-173)$ & $165(158-172)$ & $<0,0001$ \\
\hline Haskörfogat (cm) & $80(77-84)$ & $93(91-101)$ & $114(104-123)$ & $<0,001$ \\
\hline Vérnyomás (Hgmm) & $136 / 80$ & $141 / 82$ & $149 / 86$ & $<0,001$ \\
\hline C-reaktív protein $(\mathrm{mg} / \mathrm{l})$ & $4(1-16)$ & $6(2-18)$ & $7(3-21)$ & 0,123 \\
\hline Összkoleszterin (mmol/l) & $5,1(4,6-6,0)$ & $5,2(4,4-6,1)$ & $5,3(4,4-6,2)$ & 0,531 \\
\hline LDL-koleszterin & $2,9(2,2-3,5)$ & $2,9(2,2-3,5)$ & $3,0(2,8-3,8)$ & 0,228 \\
\hline HDL-koleszterin & $1,5(1,2-1,7)$ & $1,4(1,2-1,7)$ & $1,3(1,0-1,5)$ & 0,022 \\
\hline Triglicerid (mmol/1) & $1,3(1-1,6)$ & $1,4(1-1,9)$ & $1,6(1,2-2,1)$ & 0,047 \\
\hline Vércukor (mmol/1) & $5,8(5-7,3)$ & $5,9(4,9-7,9)$ & $6,2(5,2-8,4)$ & 0,569 \\
\hline $\mathrm{HbA}_{\mathrm{lc}}(\mathrm{mmol} / \mathrm{mol})$ & $38,7(34-44)$ & $37,6(34-40)$ & $38,2(35-45)$ & 0,332 \\
\hline $\mathrm{FEV}_{1} \mathrm{ref} \%$ & $41(34-48)$ & $45(36-54)$ & $49(40-62)$ & 0,049 \\
\hline FVC (\%) & $70(60-82)$ & $72(59-85)$ & $69(59-81)$ & 0,543 \\
\hline $\mathrm{FEV}_{1} / \mathrm{FVC}(\%)$ & $45(38-52)$ & $49(41-61)$ & $56(49-65)$ & $<0,0001$ \\
\hline \multicolumn{5}{|l|}{ GOLD-stádiumok } \\
\hline GOLD A (fö, \%) & $1(3,85)$ & $6(7,14)$ & $10(5,26)$ & 0,054 \\
\hline GOLD B (fö, \%) & $5(19,23)$ & $23(27,39)$ & $77(40,53)$ & \\
\hline GOLD C (fö, \%) & $18(69,23)$ & $38(45,23)$ & $82(43,16)$ & \\
\hline GOLD D (fö, \%) & $2(7,69)$ & $17(20,24)$ & $21(11,05)$ & \\
\hline SGRQ-C, tünet & $72,2(62,5-77,1)$ & $65,4(53,1-74,9)$ & $64,6(51,6-74,0)$ & 0,006 \\
\hline SGRQ-C, aktivitás & $72,4(66,2-78,6)$ & $64,9(52,0-73,2)$ & $65,8(53,9-73,0)$ & 0,014 \\
\hline SGRQ-C, hatás & $48,5(33,9-62,4)$ & $33,4(20,1-46,1)$ & $34,8(25,3-45,9)$ & 0,002 \\
\hline SGRQ-C, teljes & $56,8(42,5-67,0)$ & $48,7(33,9-62,4)$ & $49,8(34,0-63,1)$ & 0,002 \\
\hline \multicolumn{5}{|l|}{ Társbetegségek (n, \%) } \\
\hline Ischaemiás szívbetegség & $12(46,15)$ & $34(40,48)$ & $115(60,53)$ & 0,011 \\
\hline Hypertonia & $16(61,53)$ & $60(71,43)$ & $160(84,21)$ & 0,007 \\
\hline Diabetes mellitus & $2(7,69)$ & $12(14,29)$ & $50(26,31)$ & 0,020 \\
\hline Metabolikus szindróma & $9(34,61)$ & $51(60,71)$ & $156(82,11)$ & $<0,0001$ \\
\hline Pszichiátriai betegség & $1(3,85)$ & $10(11,90)$ & $28(14,74)$ & 0,156 \\
\hline 6MWD (m) & $218(130-290)$ & $292(170-368)$ & $250(150-335)$ & 0,089 \\
\hline Exacerbatiók száma az előző évben/alkalom & $3(1-6)$ & $1(0-3)$ & $2(0-6)$ & $<0,001$ \\
\hline
\end{tabular}

A táblázat adatai medián és interkvartilis terjedelemben kerültek bemutatásra.

$6 \mathrm{MWD}=6$ perces sétatávolság; $\mathrm{BMI}=$ testtömegindex; COPD = krónikus obstruktív tüdőbetegség; HbA $\mathrm{lc}_{\mathrm{c}}=$ hemoglobin-Alc $(\mathrm{glikált} \mathrm{hemo-}$

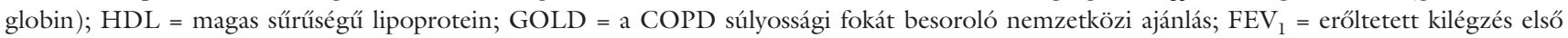
másodpercében kifújt volumen; FVC = erőltetett kilégzési vitálkapacitás; IQR = interkvartilis tartomány; LDL = alacsony sűrüségű lipoprotein; SGRQ = Szent György-féle Légzési Kérdőív

Szignifikanciaszint: $\mathrm{p}<0,05$ 
2. táblázat |A COPD-s betegek funkcionális jellemzói metabolikus szindróma szerint csoportosítva

\begin{tabular}{|c|c|c|c|c|}
\hline & $\begin{array}{c}\text { MetS } \\
\mathrm{n}=216\end{array}$ & $\begin{array}{l}\text { MetS nélkül } \\
\mathrm{n}=84\end{array}$ & $\begin{array}{c}\text { Teljes } \\
\mathrm{n}=300\end{array}$ & p-érték \\
\hline Kor (év) (IQR) & $67(61-73)$ & $68(65-73)$ & $67(62-73)$ & 0,531 \\
\hline Férfi (fö, \%) & $91(42,13)$ & $47(55,95)$ & $138(46,00)$ & 0,031 \\
\hline Nő (fö, \%) & $125(57,87)$ & $37(44,05)$ & $162(54,00)$ & \\
\hline \multicolumn{5}{|l|}{ Dohányzási státusz } \\
\hline Aktívan dohányzó (fó, \%) & $88(40,74)$ & $35(41,66)$ & $123(41,00)$ & 0,447 \\
\hline Dohányzott (fö, \%) & $118(54,63)$ & $40(47,62)$ & $158(52,66)$ & \\
\hline Nem dohányzó (fö, \%) & $10(4,63)$ & $9(10,72)$ & $19(6,33)$ & \\
\hline \multicolumn{5}{|l|}{ Életminőség } \\
\hline SGRQ-C, tünet & $67,6(56,5-74,3)$ & $66,1(52,5-77,1)$ & $66,9(52,0-73,1)$ & 0,871 \\
\hline SGRQ-C, aktivitás & $67,9(47,4-79,7)$ & $65,5(51,6-69,1)$ & $66,6(51,5-77,3)$ & 0,579 \\
\hline SGRQ-C, hatás & $35,8(30,3-48,0)$ & $34,2(29,1-46,1)$ & $35,0(21,3-49,9)$ & 0,436 \\
\hline SGRQ-C, teljes & $51,6(33,9-62,4)$ & $50,1(35,9-64,0)$ & $50,8(33,9-62,4)$ & 0,605 \\
\hline $\mathrm{FEV}_{1} \mathrm{ref} \%$ & $47(36-58)$ & $48(36-61)$ & $47,5(37-59)$ & 0,702 \\
\hline FVC (\%) & $69(59-81)$ & $71(60-87)$ & $70(59-83)$ & 0,294 \\
\hline $\mathrm{FEV}_{1} / \mathrm{FVC}(\%)$ & $54(45-64)$ & $51(45-61)$ & $53(45-64)$ & 0,070 \\
\hline $\mathrm{BMI}\left(\mathrm{kg} / \mathrm{m}^{2}\right)$ & $28,7(24,7-33,2)$ & $23,8(21,5-27,5)$ & $27,2(23,5-32,2)$ & $<0,0001$ \\
\hline 6MWD (m) & $250(150-330)$ & $295(162-360)$ & $253(153,7-342,7)$ & 0,384 \\
\hline Exacerbatiók száma az előző évben & $3(0-6)$ & $1(1-2)$ & $2(0-6)$ & $<0,001$ \\
\hline Szteroidhasználat az előző évben & $3(1-4)$ & $1(0-2)$ & $2(1-3)$ & $<0,001$ \\
\hline
\end{tabular}

A táblázat adatai medián és interkvartilis terjedelemben kerültek bemutatásra.

6MWD = 6 perces sétatávolság; $\mathrm{BMI}=$ testtömegindex; $\mathrm{COPD}=$ krónikus obstruktív tüdőbetegség; $\mathrm{FEV}_{1}=$ erőltetett kilégzés első másodpercében kifújt volumen; FVC = eróltetett kilégzési vitálkapacitás; IQR = interkvartilis tartomány; MetS = metabolikus szindróma; SGRQ = Szent György-féle Légzési Kérdőív

Szignifikanciaszint: $\mathrm{p}<0,05$

3. táblázat |A COPD-s betegek súlyossági osztályozása és ennek megfelelően a paraméterek összehasonlítása a GOLD-stádiumok szerint

\begin{tabular}{|c|c|c|c|c|c|}
\hline & $\begin{array}{c}\text { GOLD A } \\
\mathrm{n}=17\end{array}$ & $\begin{array}{c}\text { GOLD B } \\
\mathrm{n}=105\end{array}$ & $\begin{array}{c}\text { GOLD C } \\
\mathrm{n}=138\end{array}$ & $\begin{array}{c}\text { GOLD D } \\
\mathrm{n}=40\end{array}$ & p-érték \\
\hline Kor (év) (IQR) & $65(60-75)$ & $67(63-73)$ & $68(64-73)$ & $64(59-70)$ & 0,139 \\
\hline Férfi (fö, \%) & $5(29,41)$ & $52(49,52)$ & $61(44,20)$ & $20(50,00)$ & 0,120 \\
\hline Nő (fö, \%) & $12(70,59)$ & $53(50,48)$ & $77(55,80)$ & $20(50,00)$ & \\
\hline Metabolikus szindróma (f', \%) & $14(82,3)$ & $74(70,5)$ & $98(71,0)$ & $30(75,0)$ & 0,311 \\
\hline 6MWD (m) & $300(184-362)$ & $250(200-400)$ & $247(150-320)$ & $220(102-297)$ & $<0,001$ \\
\hline $\mathrm{FEV}_{\mathrm{l}} \mathrm{ref} \%$ & $90(86-97)$ & $62(54-69)$ & $43(37-47)$ & $23(19-26)$ & $<0,0001$ \\
\hline $\mathrm{FVC}(\%)$ & $108(101-116)$ & $79(70-91)$ & $66(59-74)$ & $49(43-54)$ & $<0,0001$ \\
\hline $\mathrm{FEV}_{1} / \mathrm{FVC}(\%)$ & $69(65-70)$ & $62(54-67)$ & $50(44-56)$ & $37(33-44)$ & $<0,0001$ \\
\hline
\end{tabular}

A táblázat adatai medián és interkvartilis terjedelemben kerültek bemutatásra.

$6 \mathrm{MWD}=6$ perces sétatávolság; $\mathrm{COPD}=$ krónikus obstruktív tüdőbetegség; $\mathrm{FEV}_{1}$ = erőltetett kilégzés első másodpercében kifújt volumen; $\mathrm{FVC}=$ erôltetett kilégzési vitálkapacitás; GOLD = a COPD súlyossági fokát besoroló nemzetközi ajánlás; $\mathrm{IQR}=$ interkvartilis tartomány

Szignifikanciaszint: $\mathrm{p}<0,05$ 


\section{Megbeszélés}

Tanulmányunk célja volt a metabolikus szindróma prevalenciájának meghatározása COPD-s betegekben, akik különböző tápláltsági állapotban és GOLD-stádiumokban voltak. A hasi elhízás, a magas vérnyomás, a hyperglykaemia, valamint a metabolikus szindróma is különösen a túlsúlyos/elhízott csoportban $\left(\mathrm{BMI} \geq 25 \mathrm{~kg} / \mathrm{m}^{2}\right.$; $\mathrm{p}<0,001$ ) volt gyakoribb. A betegek $72 \%$-ában metabolikus szindrómát találtunk; ez a prevalencia magasabb a korábbi vizsgálatokhoz képest, amelyek 21\% és 58\% közötti értéket mutattak [13]. Ennek magyarázata lehet a különböző metabolikusszindróma-kritériumok alkalmazása; jelen kutatásunkban a legszigorúbb IDF-kritérium szerinti definíció került alkalmazásra, és a kórházba kerülő betegek szinte mindegyike $(89,4 \%)$ különböző társbetegségekkel küzdött, például ischaemiás szívbetegség, hypertonia, cukorbetegség.

A metabolikus szindróma, vagy „kardiometabolikus szindróma" kifejezést manapság gyakran használják a cardiovascularis, vese-, metabolikus, prothromboticus és gyulladásos rendellenességek kölcsönhatásának leírására, mely megnövekedett morbiditást és mortalitást okoz COPD-s betegekben. Számos tanulmány értékelte a COPD és a vér lipidprofilját, de az eredmények továbbra is ellentmondásosak. Gunay és mtsai megállapították, hogy a szérum HDL-koleszterin-szintje szignifikánsan alacsonyabb, míg a trigliceridszint szignifikánsan magasabb a stabil COPD-s betegek között, mint a kontrollok esetében [14]. Xuan és mtsai arról számoltak be, hogy nincs különbség a szérum triglicerid-, teljeskoleszterinés LDL-koleszterin-szintje között a COPD-s betegek és a kontrollszemélyek között [15]. Breyer és mtsai közleménye szerint a metabolikus szindróma gyakoribb a túlsúlyos és elhízott COPD-s betegek között [16]. Can és kutatótársai megvizsgálták a betegség súlyosságát és a szérumlipidszinteket, és megállapították, hogy súlyosabb COPD-stádiumokban (GOLD III. és IV.) szignifikánsan alacsonyabb a HDL-koleszterin-szint, mint a kontrollszemélyekben [17]. Jelen kutatásunkban a lipidprofilban a túlsúlyos betegek között $\left(\mathrm{BMI}>25 \mathrm{~kg} / \mathrm{m}^{2}\right)$ szignifikánsan emelkedett trigliceridszintet és szignifikánsan csökkent HDL-koleszterin-szintet detektáltunk; a metabolikus szindrómában szenvedő betegek szignifikánsan magasabb BMI-vel rendelkeztek, mint a metabolikus szindróma nélküli betegek.

A légzésrehabilitációs programban részt vevő COPD-s betegek közel fele túlsúlyos vagy elhízott, ami negatívan befolyásolja a légzésfunkciót és a terhelési toleranciát, különösen járás közben; a COPD-s betegek körében azonban olyan paradoxont írtak le, amely szerint a magasabb BMI-vel rendelkező betegek hosszabb ideig élnek, mint az alacsony BMI-vel rendelkező vagy normál tápláltsági állapotú társaik. Ez a jelenség vagy paradoxon, az „obesity paradox” azonban 30-as BMI-érték felett eltünik, és az obesitas, a fizikai inaktivitás és a társbetegségek egyértelmúen negatívan befolyásolják a COPD-ben szenvedő betegek túlélését [18-20].

A gyógyszerek közvetlenül befolyásolhatják a metabolikus szindróma prevalenciáját, például az orális glükokortikoidok növelik a vér glükózszintjét, az LDL-koleszterin-szintet és az étvágyat, valamint izomatrófiát és hasi elhízást okozhatnak [21]. A COPD egyéb gyakori gyógyszerei, mint például az antidepresszánsok, csökkent glükóztoleranciát okozhatnak [22], s ezzel hozzájárulnak a metabolikus szindróma kialakulásához.

Néhány közelmúltbeli tanulmány azonosította a COPD-s betegek úgynevezett „együttes morbiditási altípusát" (co-morbidity predominant subtype), amelyet egy metabolikus társbetegségcsoport jellemez, beleértve a cardiovascularis betegségeket, a 2-es típusú cukorbetegséget és az elhízást; kimutatták, hogy a cardiovascularis betegségekkel, magas vérnyomással és 2-es típusú cukorbetegséggel is küzdő betegek fokozott kockázattal élnek a morbiditás és a mortalitás szempontjából [23]. Különös jelentőséget kell tulajdonítani az ülő helyzetnek vagy a mindennemú mozgást korlátozó állapotnak, mert az ülő helyzet időtartama szignifikáns korrelációt mutat a vércukorszinttel és a haskörfogattal. Már alacsony intenzitású fizikai aktivitás is előnyösebb metabolikus helyzetet teremthet [24]. A súlycsökkenés önmagában befolyásol számos, az elhízásban nagyon gyakori kockázati tényezôt, mint például a magas vérnyomást, a dyslipidaemiát és az inzulinrezisztenciát. A különböző kutatások megvizsgálták a testmozgás hatását túlsúlyos és elhízott betegek esetében, és a vérnyomás, a lipidprofilok, a glükóz, a glikált hemoglobin $\left(\mathrm{HbA}_{\mathrm{lc}}\right)$ és az inzulinérzékenység javulását írták le. Úgy tünik, hogy a testmozgás időtartama sokkal fontosabb, mint a testmozgás módozata [25].

Összességében az aerob testmozgás bármilyen intenzitáson jótékony hatással van a metabolikus szindróma összes komponensére túlsúlyos vagy elhízott betegek esetén [26-29].

\section{Következtetés}

Eredményeink azt sugallják, hogy a metabolikus szindrómás betegekben megnő az együttes morbiditási index, különösen azoknál, akik túlsúlyosak vagy elhízottak. Ezért a COPD-s betegek esetében nagyon fontos időben felismerni és megfelelően kezelni a metabolikus szindrómát. Jelen tanulmányunk keresztmetszeti kutatás volt; további, longitudinális prospektív vizsgálatok szükségesek annak tanulmányozására, hogy a metabolikus szindrómának milyen hosszú távú hatásai vannak a COPD-s betegek cardiovascularis és egyéb megbetegedéseire.

Anyagi támogatás: A szerzők a cikk megírása, illetve a kutatómunka során anyagi támogatásban nem részesültek.

Szerzői munkamegosztás: F. M., F.-P. V.: A kérdőívek feldolgozása, irodalomkutatás, cikkírás. Sz. G.: A statisztika 
ellenőrzése. V. J. T.: Irodalomkutatás, a kézirat megszövegezése, ellenőrzése, végső formába öntése. A cikk végleges változatát valamennyi szerző elolvasta és jóváhagyta.

Érdekeltségek: A szerzőknek nincsenek érdekeltségeik.

\section{Köszönetnyilvánítás}

Köszönjük koordinátorunknak, Kecskés Anitának a kérdőívek kitöltésében nyújtott segítségét és az Országos Korányi Pulmonológiai Intézet betegeinek értékes válaszait, amelyekkel segítették a kutatást.

\section{Irodalom}

[1] Varga J. Chronic obstructive pulmonary disease. [Krónikus obstruktív tüdőbetegség.] Háziorv Továbbk Szle. 2018; 23: 2630. [Hungarian]

[2] Fekete M, Pongor V, Fehér A, et al. Relationship of chronic obstructive pulmonary disease and nutritional status - clinical observations. [Krónikus légzőszervi betegek tápláltsági állapotának vizsgálata - klinikai megfigyelések.] Orv Hetil. 2019; 160: 908913. [Hungarian]

[3] Varga J. Theoretical and clinical basics of respiratory rehabilitation and areas of care. [A légzésrehabilitáció elméleti és gyakorlati alapjai, ellátási színterei.] Korányi Bull. 2016; 1: 44-47. [Hungarian]

[4] Böszörményi Nagy Gy, Balikó Z, Kovács G, et al. Protocol on diagnosis and therapy of the basic and emergency management of patients affected by chronic obstructive pulmonary disease. [Egészségügyi szakmai irányelv a krónikus obstruktív tüdőbetegség (COPD) diagnosztikájáról és kezeléséról az alap-, a szak- és a sürgősségi ellátás területére.] Med Thor. 2014; 67(Suppl): 79113. Available from: https://www.copdplatform.com/res/file/ national-documents/hun-guidelines.pdf [accessed: May 11, 2020].

[5] Doehner W, Haeusler KG, Endres M, et al. Neurological and endocrinological disorders: orphans in chronic obstructive pulmonary disease. Resp Med. 2011; 105: S12-S19.

[6] Krychtiuk KA, Kastl SP, Pfaffenberger S, et al. Association of small dense LDL serum levels and circulating monocyte subsets in stable coronary artery disease. PLoS ONE 2015; 10: 4.

[7] Mroz R, Lisowski P, Tycinska A, et al. Anti-inflammatory effects of atorvastatin treatment in chronic obstructive pulmonary disease. Physiol Pharmacol. 2015; 66: 111-128.

[8] Vágvölgyi A, Rozgonyi Z, Vadász P, et al. Risk stratification before thoracic surgery, perioperative pulmonary rehabilitation. [A mellkassebészeti mútéti teherbíró képesség megítélése, perioperatív légzésrehabilitáció.] Orv Hetil. 2017; 158: 1989-1997. [Hungarian]

[9] International Society for Pediatric and Adolescent Diabetes. IDF/ISPAD 2011 global guideline for diabetes in childhood and adolescence. ISPAD, Berlin, 2016

[10] Global Initiative for Chronic Obstructive Lung Disease (GOLD) 2019. Global strategy for the diagnosis, management and prevention of chronic obstructive lung disease. 2019 report. Available from: http://goldcopd.org/ [accessed: May 23, 2020].

[11] Jones PW, Quirk FH, Baveystock CM, et al. A self-complete measure for health status for chronic airflow limitation. The St. George's Respiratory Questionnaire. Am Rev Respir Dis. 1992; 145: 1321-1327.

[12] ATS Committee on Proficiency Standards for Clinical Pulmonary Function Laboratories. ATS statement: guidelines for the sixminute walk test. Am J Respir Crit Care Med. 2002; 166: 111117. [Erratum: Am J Respir Crit Care Med. 2016; 193: 1185.]

[13] Cebron Lipovec N, Beijers RJ, van den Borst B, et al. The prevalence of metabolic syndrome in chronic obstructive pulmonary disease: a systematic review. COPD 2016; 13: 399-406.
[14] Gunay S, Sariaydin M, Acay A. New predictor of atherosclerosis in subjects with COPD: atherogenic indices. Respir Care 2016; 61: 1481-1487.

[15] Xuan L, Han F, Gong L, et al. Association between chronic obstructive pulmonary disease and serum lipid levels: a meta-analysis. Lipids Health Dis. 2018; 17: 263.

[16] Breyer MK, Spruit MA, Hanson CK, et al. Prevalence of metabolic syndrome in COPD patients and its consequences. PLoS ONE 2014; 9: e98013.

[17] Can U, Yerlikaya FH, Yosunkaya S. Role of oxidative stress and serum lipid levels in stable chronic obstructive pulmonary disease. J Chin Med Assoc. 2015; 78: 702-708.

[18] Varga J, Porszász J, Boda K, et al. Supervised high intensity continuous and interval training as well as home training in the rehabilitation of chronic obstructive pulmonary patients. [Felügyelt magas intenzitású folyamatos és intervallum, valamint otthoni tréning hatásának vizsgálata krónikus obstruktív tüdóbetegek rehabilitációjában.] Med Thorac. 2008; 61: 135-143. [Hungarian]

[19] Varga J. Mechanisms to dyspnoea and dynamic hyperinflation related exercise intolerance in COPD. Acta Physiol Hung. 2015; 102: 163-175.

[20] Garcia-Aymerich J, Lange P, Benet M, et al. Regular physical activity reduces hospital admission and mortality in chronic obstructive pulmonary disease: a population based cohort study. Thorax 2006; 61: 772-778.

[21] Diez-Manglano J, Barquero-Romero J, Almagro P, et al. COPD patients with and without metabolic syndrome: clinical and functional differences. Intern Emerg Med. 2014; 9: 419-425.

[22] Khoza S, Barner JC. Glucose dysregulation associated with antidepressant agents: an analysis of 17 published case reports. Int J Clin Pharm. 2011; 33: 484-492.

[23] Vanfleteren LE, Spruit MA, Groenen M, et al. Clusters of comorbidities based on validated objective measurements and systemic inflammation in patients with chronic obstructive pulmonary disease. Am J Respir Crit Care Med. 2013; 187: 728-735.

[24] Kerti M, Balogh Zs, Kelemen K, et al. The relationship between exercise capacity and different functional markers in pulmonary rehabilitation for COPD. Int J Chron Obstruct Pulmon Dis. 2018; 13: 717-724.

[25] Varga J, Szilasi M, Balogh Zs. Handbook of pulmonary rehabilitation. [A pulmonológiai rehabilitáció kézikönyve.] SpringMed Kiadó, Budapest, 2018. [Hungarian]

[26] Vágvölgyi A, Rozgonyi Z, Kerti M et al. Effectiveness of pulmonary rehabilitation and correlations in between functional parameters, extent of thoracic surgery and severity of post-operative complications: randomized clinical trial. J Thorac Dis. 2018; 10: 3519-3531.

[27] Hegedús B, Varga J, Somfay A. Interdisciplinary rehabilitation in patients with ankylosing spondylitis. [Az interdiszciplináris rehabilitáció hatása spondylitis ankylopoeticában szenvedő betegeknél.] Orv Hetil. 2016; 157: 1126-1132. [Hungarian]

[28] Varga J, Boda K, Somfay A. The effect of controlled and uncontrolled dynamic lower extremity training in the rehabilitation of patients with chronic obstructive pulmonary disease. [A kontrollált es nem kontrollált alsó végtagi dinamikus tréning hatása krónikus obstruktív tüdőbetegségben szenvedők rehabilitációjában.] Orv Hetil. 2005; 146: 2249-2255. [Hungarian]

[29] Varga J, Pálinkás A, Lajkó I, et al. Pulmonary arterial pressure response during exercise in COPD: a correlation with C-reactive protein (hsCRP). Open Respir Med J. 2016; 10: 1-11.

(Fekete Mónika dr., Budapest, Nagyvárad tér 4., 1089 e-mail: fekete.monika@med.semmelweis-univ.hu) 